\title{
PENGARUH CITRA LAYANAN KOPERASI TERHADAP PARTISIPASI ANGGOTA
}

\author{
Ery Supriyadi Rustidja ${ }^{1}$, Umi Untari ${ }^{1}$, Tuti Karyani ${ }^{2}$, dan Nurul Risti M. ${ }^{4}$ \\ ${ }^{1}$ Institut Koperasi Indonesia, Jl. Raya Bandung-Sumedang km 20,5. Jatinangor \\ ${ }^{2}$ Departemen Sosial Ekonomi Pertanian, Faperta, Universitas Padjadjaran Jl. Raya Bandung- \\ Sumedang km 21. Jatinangor \\ ${ }^{3}$ Faperta, Universitas Siliwangi. Tasikmalaya
}

\begin{abstract}
ABSTRAK
Ekspektasi sekaligus realitas terhadap sesuatu dapat menimbulkan kesan, pembentukan citra, keyakinan, persepsi, kognisi, sikap, motivasi, dan tindakan. Artikel ini menyajikan hasil kajian adanya fenomena partisipasi anggota koperasi yang tinggi yang berawal dari tingkat sukarelaan anggota yang tinggi sebagai akibat dari pelayanan yang prima pada suatu koperasi. Dengan menggunakan metode studi kasus, dengan analisis multikriteria dan analisis korelasi, maka diperoleh hasil kajian yang menunjukkan bahwa pencitraan yang positif melalui pelayanan prima pada unit usaha simpan pinjam koperasi dapat memberikan manfaat internal dan eksternal bagi pengembangan koperasi. Pencitraan koperasi memiliki hubungan yang erat dengan partisipasi anggota baik sebagai pemilik maupun pelanggan. Semakin baik citra koperasi dimata anggota dalam pelayanannya maka semakin tinggi partisipasi kontributif dan insentifnya.
\end{abstract}

Kata kunci : citra, partisipasi, anggota, koperasi, layanan prima

\begin{abstract}
Expectations as well as the reality of something can create an impression, image formation, belief, perception, cognition, attitude, motivation, and action. This article presents the results of the study of the phenomenon of participation of members of a high co-operative which started from the high volunteer level of members as a result of excellent service in a cooperative. By using case study method, with multicriteria analysis and correlation analysis, the result of the study showed that positive image through excellent service at cooperative savings and loan business unit can provide internal and external benefit for cooperative development. Cooperative imaging has a close relationship with the participation of both members as owners and customers. The better the image of the cooperative in its service, so the higher the contribution and incentive participation of its members.
\end{abstract}

Keywords: image, participation, members, cooperatives, excellent service 


\section{PENDAHULUAN}

Survey lapangan ditemui bahwa bahwa suatu koperasi fungsional (KPRI X) di Provinsi $\mathrm{Y}$ ternyata mengalami peningkatan jumlah yang semakin tinggi dari tahun ke tahun. Keanggotaan di koperasi ini mengalami peningkatn terus menerus sepanjang tahun berkisar antar $2-5 \%$ per tahun. Demikian pula masuknya anggota pada koperasi ini jauh lebih besar dibandingkan yang keluar.

Keluarnya anggota koperasi berhubungan dengan berhenti bekerja, pensiun, mutasi, atau meninggal dunia. Jumlah anggota koperasi yang masuk setiap tahunnya rata-rata mencapai 150-200\% lebih besar dari yang keluar.

Penambahan anggota baru koperasi ini secara sukarela lebih besar daripada yang keluar. Pertanyaannya adalah mengapa anggota koperasi semakin banyak, apakah ini menunjukkan minat kesukarelaan kenggotaan koperasi, atau apa sebenarnya yang melatarbelakangi kemauan pegawai untuk menjadi anggota koperasi secara sukarela, tanpa paksaan. Walaupun keuntungan bukanlah tujuan koperasi, namun usaha koperasi harus berjalan baik, efisien, memberi promosi bagi anggota, memberikan pelayanan prima bagi usaha anggota dan kesejahteraan anggota.

Koperasi adalah badan usaha yang beranggotakan orang-seorang atau badan hukum koperasi dengan melandaskan kegiatannya berdasar prinsip-prinsip koperasi sekaligus sebagai gerakan ekonomi rakyat yang berdasar atas asas kekeluargaan. (pasal 1 ayat 1 Undang-undang Republik Indonesia Nomor 25 Tahun1992 tentang Perkoperasian. Hendar dan Kusnadi (1999) menyebutkan bahwa kesuksesan koperasi, kebermanfaatan koperasi, dan perkembangan maju mundurnya koperasi ditentukan oleh partisipasi aktif anggotanya, anggota koperasi adalah pemilik sekaligus pelanggan (Ropke, 2000; Ramudi, 1997; Hanel,1989; Soewardi, 1995).

Keaktifan anggota koperasi menjadi salah satu kunci keberhasilan organisasi dan usaha koperasi dalam jangka pendek, menengah maupun jangka panjang. Pertanyaannya adalah bagaimana koperasi membangun iklim kondusif yang menarik minat anggota berpartipasif aktif, bagaimana menggerakankan persepsi positif anggota terhadap terhadap koperasi, dan bagaimana partisipasi aktif dalam berkoperasi dapat hidup dan berkembang pada lembaga koperasi yang tumbuh berbasis sukarela. Dengan demikian, persepsi berkoperasi, layanan koperasi, pencitraan koperasi dalam menggerakkan pemahaman koperasi, sikap menerima prinsip dan nilai koperasi, berperilaku kerjasama, dan pelayanan koperasi yang prima menjadi sangat krusial dalam menjalankan roda usaha maupun organisasi koperasi.

Pada sisi pelayanan koperasi, KPRI X ini menunjukkan kinerja usaha yang relatif stabil dan cenderung meningkat kinerja pendapatannya. Target pendapatan usaha simpan pinjam mengalami peningkatan setiap tahun yang diikuti dengan capaian yang cukup tinggi, rata-rata lebih dari 105 persen dari target awal. Disamping itu, simpanan anggota pada KPRI X ini berada dalam kuat dan mandiri. Hal ini dapat dilihat dari keadaan modal sendiri dan simpan pinjam semakin meningkatkan dari tahun ke tahun rata-rata di atas $15 \%$ per tahun. Selain itu, modal sendiri dan simpan pinjam koperai ini memiliki kemampuan likuiditas dan solvabilitas yang tinggi untuk menutupi modal lainnya yang diperoleh dari pihak perbankan.

Layanan usaha koperasi pada unit simpan pinjam dapat dilihat dari volume usahanya. Terjadi peningkatan volume usaha yang mencapai rata-rata $130 \%$ per tahun. Keadaan ini sejalan dengan peningkatan keaktifan anggota dalam menyimpan dan meminjam pada unit usaha simpan pinjam Koperasi Fungsional X ini. Jumlah pinjaman dan pengembalian pinjaman berjalan baik dan efektif.

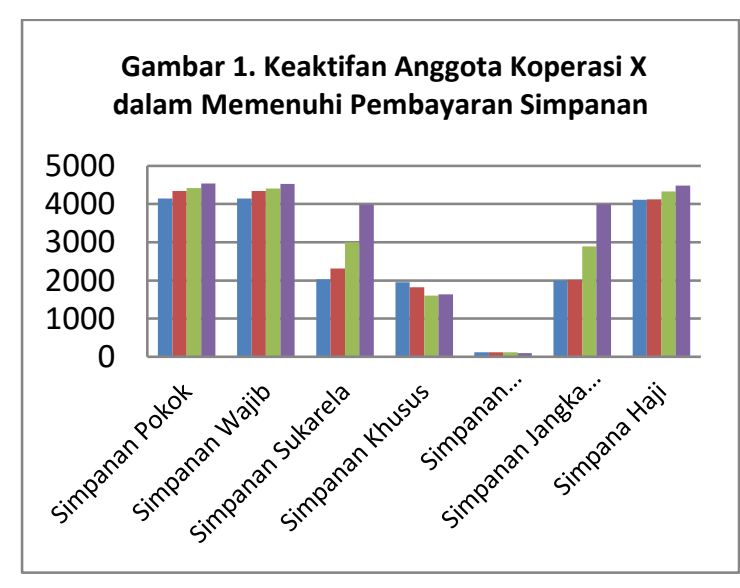

Gambar 1.

Keaktifan anggota dalam Memenuhi pembayaran simpanan 
Selama beberapa tahun terakhir, data menunjukkan bahwa kinerja simpanan anggota koperasi relatif baik (Gambar1). Walaupun terdapat kelambanan anggota dalam membayar simpanan khusus, simpanan sukarela dan simpanan perumahan. Namun demikian, anggota umumnya banyak aktif dalam membayar simpanan haji, simpanan wajib, dan simpanan jangka panjang, bahkan jumlahnya semakin meningkat dari tahun ke tahun. Data juga menunjukkan bahwa pengembalian pinjam termasuk kategori lancar mencapai $99,7 \%$ atau hanya $0.3 \%$ yang tergolong kredit macet. Hal ini menunjukkan keaktifan anggota dalam berkontriusi terhadap layanan koperasi.

Dari sisi keaktifan anggota dalam menghadiri rapat anggota relatif terbatas. Dengan jumlah anggota yang cukup besar (4500 orang) yang tersebar pada berbagai instansi dan kantor pada berbagai lokasi kabupaten dan kota, maupun kesibukan pekerjaan anggota, maka kehadiran anggota koperasi dilaksanakan berdasarkan sistem perwakilan. Rata-rata hanya $4 \%$ atau sebesar 180 orang per tahun yang menghadiri Rapat Anggota Tahunan sebagai perwakilan anggota, dimana perwakilan merupakan wakil dari 25 orang per kelompok anggota. Disamping pertimbangan lokasi dan pelaksanaan RAT, setiap anggota memiliki keterbatasn waktu dan kesibukan sehingga anggota terbatas berpartisipasi dalam menghadiri rapat anggota. Padahal partisipasi anggota menghadiri rapat anggota tahunan juga merupakan instrumen keberadaan koperasi. Kehadiran anggota dalam rapat anggota, keaktifan dalam menyetor uang simpanan, menggunakan layanan simpanan pinjam, lancarnya pengembalian pinjaman, dan ikut aktif dalam pengambilan keputusan bagi terselenggaraanya koperasi menjadi unsur keberadaan dan citra koperasi.

Pada unit simpan pinjam KPRI X menyediakan brosur mengenai simpan pinjam, menyediakan layanan mesin penghitung uang, menyediakan layanan simpanan haji untuk anggota dengan cara melakukan undian setiap tahunannya pada saat pelaksanaan RAT Koperasi. Koperasi memberikan pinjaman tanpa jaminan, ramah terhadap anggota, adanya hubungan yang baik antara karyawan koperasi dan anggota yang dilayani. Disamping itu, koperasi memiliki modal yang relatif cukup besar pada USP, menyediakan iuran sosial abgai anggota, suku bunga pinjaman yang tetap dan terjangkau bagi anggota selama 1-5 tahun (14\% - 14,5\% per tahun).

Disamping layanan yang prima terhadap anggota, koperasi ini juga memiliki ruangan yang bersih. Kondisi ini berujung pada minta anggota untuk berpartisipasi dalam menabung, membayar simpanan, keinginan anggota untuk meminjam, keinginan anggota untuk mendapat peluang beribadah haji dari simpanan haji itu sendiri. Pertanyaan yang muncul adalah bagaimana koperasi membangun citra bagi anggotanya; bagaimana anggota berpartisipasi pada koperasi tersebut, apakah berkait dengan citra yang dilakukan melalui program pengembangan dan perbaikan citra koperasi melalui pelayanannya; atau bagaimana kinerja koperasi dapat membangun kepercayaan dan pertisipasi anggota, sehingga koperasi itu dirasakan keberadaannya oleh anggota dan muncul realitas citra koperasi positif di mata anggota dan masyarakat.

Eksistensi dan citra suatu lembaga itu ada jika ada dan diadakan baik secara nyata walaupun seringkali tidak nampak secara kasat mata, namun jelas adanya. Priyatna dan Ardianto (2009) menyebut citra itu ada, tetapi tidak nyata atau seringkali tidak bisa digambarkan secara fisik. Citra merupakan kesan yang terbentuk dibenak masyarakat. Citra ada dalam pikiran, suatu citra akan bertahan cukup permanen pada kurun waktu tertentu, sehingga citra koperasi bagi anggotanya juga dapat diketahu, dapat diukur, dan dapat diubah. Citra dapat diketahui dengan melihat perilaku konsumen atau anggota organisasi.

Memperhatikan kondisi dan kemungkinan layanan, kinerja, partisipasi dan citra koperasi, maka terdapat beberapa hal yang menjadi fokus bahasan dalamkajian ini yaitu bagaimana proses membangunan citra koperasi yang mampu menarik minta anggota koperasi untuk berpartisipasi secara aktif. Tentunya membangun citra menggambarkan upaya dan proses pembentukan realita dan keberadaan koperasi pada unit usaha simpan pinjam yang memberi efek ganda bagi peningkatan nilai tambah layanan bagi anggota dan pendapatan usaha bagi koperasi secara timbal balik. Proses membangun citra ini diharapkan akan dapat meningkatkan partisipasi anggota pada USP KPRI X tersebut 
secara dinamis dan berkelanjutan, pertanyaannya adalah sejauhmana hubungan citra dengan partisipasi anggota dalam berkoperasi.

\section{METODE PENELITIAN}

Penelitian ini merupakan studi kasus pada suatu koperasi fungsional di Provinsi Lampung, yang dikaji secara mendalam, menggambarkan proses membangun citra koperasi, tingkat partisipasi anggota, dan hubungan citra koperasi dengan partisipasi anggota koperasi.

Penelitian dilakukan dengan analisis deskriptif dengan skala Likert dan disandingkan dengan analisis korelasi. Setiap indikator dan variabel citra layanan koperasi dan partisipasi anggota diolah dan hasilnya dideskripsikan baik secara parsial maupun keseluruhan terhadap citra maupun partisipasi anggota untuk menjelaskan gambaran tentang proses membangun citra dan partisipasi anggota yang terjadi pada objek penelitian, dengan melakukan triangulasi informasi dari pengurus, karyawan, dan anggota koperasi. Korelasi antara citra dan partisipasi anggota dimaksudkan untuk melihat apakah terdapat hubungan yang kuat dan sejauhmana keeratan hubungan antar kedua variabel dengan berbagai variasi indikator yang mempengaruhinya. Apakah ada perbedaan citra layanan USP menurut pandangan pengurus, karyawan, atau anggota koperasi

\section{KAJIAN PUSTAKA}

Pendekatan Koperasi menurut UU No 25 tahun 1992, jenis koperasi fungsi sebagai objek penelitian merupakan koperasi jasa yang memeberikan pelaqyanan jasa simpan pinjam maupun jasa layanan lainnya. Koperasi fungsi $X$, menyediakan redit, meningkatkan nilai tabungan, menciptakan kesan positif bagi anggota, partisiapsi anggota dalam RAT, anggota ikut menanam modal melalui berbagai bentuk simpanan dan anggota memanfaatkan berbagai bentuk layanan USP yang disediakan koperasi.

Koperasi bertujuan memajukan kesejahteraan anggota pada khususnya dan masyarakat pada umumnya serta ikut membangun tatanan perekonomian nasional dalam rangka mewujudkan masyarakat yang maju, adil, dan makmur berlandaskan Pancasila dan Undang-undang Dasar 1945.

Koperasi sebagai sistem sosial ekonomi (Hanel, 1989). Dalam kaitan ini, koperasi secara sosio-ekonomi membentuk struktur organisasi yang melibatkan anggota dan perusahaan koperasi, dengan keunikan anggota merupakan pemilik sekaligus sebagai pelanggan. Koperasi memeiliki hubungan kepemilikan baik seacar perorangan maupun kelompok, hubungan usaha yang bersifat menunjang bagi anggota, kegiatan ekonomi anggota, perusahaan koperasi, dan hubungan pasar yang saling berinteraksi satu dengan lainnya.

Citra atau kesan dapat merupakan hasil dari proses komunikasi., dimana komunikasi merupakan proses penyampaian pikiran atau perasaan dalam bentuk pesan oleh seseorang kepada orang lain agar mengetahui atau berubah sikap pendapat atau perilakunya (Effendi. 1988). Komunikasi juga merupkan suatu cara untuk menciptakan citra positif dari suatu organisasi atas dasar memenuhi kepentingan bersama (Sumirat dan Ardianto, 2004).

Kotler (1995) mengartikan citra sebagai sejumlah keyakinan, gambaran, dan kesan yang dipunyai seseorang pada suatu objek. Objek yang dimaksud dapat berupa orang, organisasi, kelompok orang atau yang lain yang diketahui. Jika objeknya berupa organisasi, berarti seluruh keyakinan, gambaran, dan kesan atas organisasi dari seseorang merupakan citra. Selanjutnya Sutisna (2010) mengartikan citra adalah total persepsi terhadap suatu objek yang dibentuk dengan memproses informasi dari berbagai sumber setiap waktu. Senada dengan ini, Alma (2010) mendefinisikan citra sebagai kesan yang diperoleh sesuai dengan pengetahuan dan pengalaman seseorang tentang sesuatu. Dengan berlandaskan pada pandanganpandangan ini, maka citra muncul karena proses komunikasi yang menimbulkan kesan karena pemahaman akan suatu kenyataan, sehingga kesan objek, proses pembentukan citra, dan sumber informasi yang terpercaya menjadi tiga hal penting dalam citra.

Citra menjadi fokus perhatian dari suatu organisasi, termasuk koperasi, mengingat bahwa proses penyampaian informasi kepada pihak lain (termasuk anggotakoperasi) akan terdampak oleh informasi yang disampaikan oleh organisasi, dan berujung pada pembentuk kesan yang dimunculkan dari proses komunikasi yang telah dilakukan oleh organisasi. Keadaan ini juga menjelaskan 
bahwa citra mempunyai dampak ekspektasi tertentu dari penerima pesan, sehingga menimbulkan kesan. Selain itu citra merupakan penyaring yang mempengaruhi persepsi pada kegiatan, citra membangun harapan dan realitas pengalaman dalam bentuk kualitas pelayanan, kualitas pelayanan yang dirasa akan menghasilkan perubahan citra, serta citra memiliki dampak internal bagi kegiatan organisasi/perusahaan. Berlandaskan pendapat Priyatno dan Ardianto (1990) tersebut, maka terdapat empat peran citra bagi organisasi/perusahaan, maka koperasi sebagai organisasi/perusahaan perlu membangun citra. Model pembentuk citra (Danasaputra dalam Soemirat dan Ardianto, 2004) terdiri dari pembentukan citra, stimulus, pengalaman mengensi stimulus, dan respon perilaku. Pembentukan citra berisi persepsi, kognisi, sikap, dan motivasi, yaitu hasil pengamatan terhadap lingkungan yang dikaitkan dengan proses pemaknaan, keyakinan terhadap stimulus, keadaan pribadi yang mendorong keinginan untuk melakukan kegiatan tertentu guna mencapai tujuan, kecenderungan bertindak, berpersepsi, berpikir, merasa dalam menghadapi objek, ide, situasi atau nilai tertentu. Keadaan-keadaan ini memunculkan kecenderungan perilaku dan dampak komunikasi baik manfaat internal maupun eksternal bagi organisasi/perusahaan. Citra menjadi suatu proses komunikasi yang bersifat reversible. Citra koperaqsi berarti memiliki hubungan timbal balik dari organisasi/perusahaan koperasi dengan anggota. Koperasi memeberikan pelayanan prima, sedangkan anggota bersedia untuk ikut berpartisipasi aktif pada unit usaha yang disediakan koperasi. Citra eksternal juga dapat muncul dari anggota koperasi kepada masyarakat, atau non anggota, sehingga masyarakt maupun non anggota memutuskan untuk menjadi anggota koperasi.

Secara generik Rusidi (1992) dan

Soewardi (1995) menyebutkan bahwa partisipasi anggota dapat dilihat dari partisipasi anggota dalam rapat anggota tahunan, partisipasi anggota dalam penanaman modal, dan partisipasi anggota dalam pemanfaatan pelayanan yang disediakan oleh koperasi. Selanjutnya partisipasi anggota koperasi dapat pula dilihat dari ketrlibatan anggota koperasi dalam berkontribusi dan insentif (Hendar dan Kusnadi (1999). Partisipasi kontributif berupa keterlibatan anggota mengambil bagian dalam penetapan tujuan, pembuatan keputusan, proses pengawasan terhadap jalannya organisasi/usaha koperasi; sedangkan partisipasi insentif menempatkan anggota koperasi memanfaatkan berbagai pelayanan yang disediakan koperasi dalam menunjang kepentingan anggota maupun perusahaan koperasi.

Adapun operasionalisasi variabel dalam kajian ini meliputi kajian pencitraan dan partisipasi anggota koperasi. Pencitraan berisi variabel dan indikator sebagai berikut;

1. Kesan objek

a. Kesan Objek Terhadap Individu Indikator : Keramahan Pelayanan, Mutu Pelayanan, Kemampuan pengelolaan keuangan, kecepatan proses peminjaman, jumlah pengelola, kemudahan anggota

b. Kesan Objek Terhadap organisasi/perusahaan koperasi Indikator : Peningkatan jumlah simpanan anggota, Volume usaha, Besarnya jumlah Sisa Hasil Usaha, Tenaga manajerial yang berkualitas

2. Pembentukan Citra

a. Persepsi, Indikator : evaluasi kegiatan rutin/kontinyu, penertiban administrasi, penerapan komputerisasi, sistem pembayaran yang diberikan

b. Kognisi, dengan indikator Indikator : Tanggapan kebutuhan anggota, melayani kebutuhan, jenis pelayanan yang diberikan

c. Motivasi

Indikator : Penyediaan berbagai jenis tabungan dan simpanan, besarnya maksimal jumlah pinjaman, mempertahankan suku bunga pinjaman

d. Sikap Indikator : tingkat perhatian kepada anggota, kemengertian terhadap keinginan, penerimaan keluhan, tingkat respon, kebertanggungjawaban, teknologi layanan yang digunakan

3. Sumber Informasi Terpercaya

a. Perusahaan koperasi

Indikator : penerapan sistem komputerisasi, besarnya modal yang dimiliki koperasi, peningkatan jumalh simpanan, kemudahan pelayanan, kemampuan karyawan dalam 
keuangan, jalinan hubungan karyawan dengan anggota, tanggung jawab terhadap layanan, kepedulian terhadap anggota, kecepatan tanggap terhadap keluhan, kinerja keamanan transaksi

b. Pihak lain

Indikator : prestasi USP Koperasi, pengalaman terhadap pelayanan, kesan dalam layanan USP

4. Partisipasi Anggota

a. Partisipasi kontributif

Indikator : Ketertiban pembayaran simpanan wajib, keaktifan membayar simpanan-simpanan, frekuensi pembayaran bunga pinjaman, tingkat pengembalian pinjaman, total simpanan, frekuensi membayar simpanan,

b. Partipasi insentif Indikator : Frekuensi memberi saran untuk menentukan keputusan layanan simpan pinjam, frekuensi kehadiran menghadiri rapat anggota, penyampaian keluhan dan kritikan, usulan tata cara pembayaran, keaktifan dalam memenuhi simpanan-simpanan, pengawasan terhadap kegiatan USP

\section{HASIL DAN PEMBAHASAN}

Data penelitian diperoleh dari hasil wawancara, angket dan observasi diperoleh hasil kajian sebagaimana tercantum pada Tabel 1. Hasil Rekapitulasi Citra Layanan Koperasi yang bersumber dari informasi dari pengurus, karyawan dan anggota koperasi tersaji sebagai berikut.

Kesan baik objek individu dan perusahaan koperasi termasuk lategori sangat baik, yang berarti pengurus, karyawan dan anggota memiliki kesan positif terhadap citra layanan koperasi.

Hal ini memiliki konsekuensi bahwa layanan primaq yang dilakukan Koperasi Fungsional $\mathrm{X}$ bagi anggota menjadi faktor kunci yang memberi dampak positif bagi keberlanjutan usaha USP dan manfaat ekonomi langsung bagi anggota. Kesan yang sangat baik ini berkait dengan keramahan dan mutu pelayanan, kemampuan pengelolaan keuangan, kecepatan proses peminjaman, jumlah pengelola, kemudahan anggota mendapat layanan. Kesan bersifat positif ini diikuti dengan peningkatan jumlah simpanan anggota, volume usaha, besarnya jumlah SHU, serta tenaga manajerial yang berkualitas.

Pembentukan citra layanan termasuk kategori sangat baik, baik dari subvariabel persepsi, kognisi, motivasi dan sikap, persepsi mengenai evaluasi kegiatan rutin/kontinyu, penertiban administrasi, penerapan komputerisasi, sistem pembayaran yang diberikan termasuk kategiri sangat baik. Demikian pula pengetahuan tentang tanggapan kebutuhan anggota, melayani kebutuhan, jenis pelayanan yang diberikan termasuk kategori sangat baik. Motivasi juga terbangun sangat positif yang mencakup penyediaan berbagai jenis tabungan dan simpanan, besarnya maksimal jumlah pin jaman, mempertahankan suku bunga pinjaman yang dilakukan koperasi terhadap anggota-anggota.

Hasil pembentukan citra dari sikap yang muncul juga termasuk kategori sangat baik, menyangkut indikator tingkat perhatian kepada anggota, kemengertian terhadap keinginan,

Tabel 1.

Hasil Rekapitulasi Citra Layanan Koperasi Menurut Pengurus, Karyawan dan Anggota

\begin{tabular}{lllllllll}
\hline Variabel Citra Layanan & \multicolumn{2}{l}{ Pengurus } & \multicolumn{2}{l}{ Karyawan } & \multicolumn{2}{l}{ Anggota } & \multicolumn{2}{c}{ Total } \\
\cline { 2 - 8 } Koperasi & Skor & $\mathbf{\%}$ & Skor & \% & Skor & \% & Skor & \% \\
\hline Kesan Objek Indivdu (X11) & 124 & $\mathbf{8 2 , 7}$ & 781 & $\mathbf{8 6 , 8}$ & 666 & $\mathbf{7 9 , 3}$ & 1571 & $\mathbf{8 3 , 1}$ \\
Kesan Objek Perusahaan (X12) & 96 & $\mathbf{9 6 , 0}$ & 553 & $\mathbf{9 2 , 2}$ & 505 & $\mathbf{9 0 , 2}$ & 1154 & $\mathbf{9 1 , 6}$ \\
Persepsi (x21) & 78 & $\mathbf{7 8 , 0}$ & 522 & $\mathbf{8 7 , 0}$ & 445 & $\mathbf{7 9 , 5}$ & 1045 & $\mathbf{8 2 , 9}$ \\
Kognisi (X22) & 59 & $\mathbf{7 8 , 7}$ & 402 & $\mathbf{8 9 , 3}$ & 371 & $\mathbf{8 8 , 3}$ & 832 & $\mathbf{8 8 , 0}$ \\
Motivasi (x23) & 58 & $\mathbf{7 7 , 3}$ & 383 & $\mathbf{8 5 , 1}$ & 359 & $\mathbf{8 5 , 5}$ & 800 & $\mathbf{8 4 , 7}$ \\
Sikap (x25) & 99 & $\mathbf{6 6 , 0}$ & 714 & $\mathbf{7 9 , 3}$ & 691 & $\mathbf{8 2 , 3}$ & 1504 & $\mathbf{7 9 , 6}$ \\
Sumber Terpercaya Perusahaan & & & & & & & & \\
Koperasi (x31) & 217 & $\mathbf{7 8 , 9}$ & 1357 & $\mathbf{8 2 , 2}$ & 1227 & $\mathbf{7 9 , 7}$ & 2801 & $\mathbf{8 0 , 8}$ \\
Sumber Terpercaya Perusahaan & & & & & & & & \\
lain (x32) & 49 & $\mathbf{6 5 , 3}$ & 307 & $\mathbf{6 8 , 2}$ & 290 & $\mathbf{6 9 , 0}$ & 646 & $\mathbf{6 8 , 4}$ \\
Citra Layanan USP & 780 & $\mathbf{7 8 , 0}$ & 5019 & $\mathbf{8 3 , 7}$ & 4554 & $\mathbf{8 1 , 3}$ & 10353 & $\mathbf{8 2 , 2}$ \\
\hline
\end{tabular}


penerimaan keluhan, tingkat respon, kebertanggungjawaban, Namun dari sisi teknologi layanan yang digunakan oleh koperasi termasuk kategori kurang, sehingga citra ini relatif menimbulkan sikap yang relatif lemah dan negatif bagi pembentukan citra layanan di USP Koperasi Fungsional X,

Layanan USP koperasi memebntuk kepercayaan koperasi bagi anggpta, layanan menimbulkan sumber informasi tercepat bagi anggota dalam memanfaatkannya, sehingga perusahaan koperasi membentuk citra positif yang dipercapaya oleh anggotanya. Sumber informasi terpercaya termasuk kategori sangat baik, yaitu penerapan sistem komputerisasi, besarnya modal yang dimiliki koperasi, peningkatan jumalh simpanan, kemudahan pelayanan, kemampuan karyawan dalam keuangan, jalinan hubungan karyawan dengan anggota, tanggung jawab terhadap layanan, kepedulian terhadap anggota, kecepatan tanggap terhadap keluhan, kinerja keamanan transaksi.

Layanan USP koperasi ternyata belum membentuk kepercayaan koperasi bagi pihak lain. Pendapat pengurus, karyawan, dan anggota mengenai layanan USP menjadi sumber terpercaya bagi perusahaan lain termasuk kategori cukup. Layanan USP koperasi bagi pihak lain dianggap belum berprestasi bahkan dianggap rendah pula oleh pengurus, karyawan maupun anggota, walaupun pengalaman terhadap pelayanan dan terkesan layanan USP koperasi termasuk kategori baik.

Berdasarkan kesan, pemebentukan citra, dan sumber terpercaya, secra keseluruhan termasuk kategori sangat baik. Citra layanan koperasi termasuk kategori sangat baik, berati perusahaan koperasi sangat baik memberikan layanan USP kepada anggotanya, sehingga membentuk citra yang positif. Anggota koperasi merasakan manfaat dari layanan USP mkoperasi, yang memunculkan citra positif terhadap keberadaan dan realitas Koperasi Fungsional $\mathrm{X}$ tersebut,

Partisipasi kontributif anggota koperasi termasuk lategori sangat baik. Kecuali tingkat pengembalian pinjaman, indikator ketertiban pembayaran simpanan wajib, keaktifan membayar simpanan-simpanan, frekuensi pembayaran bunga pinjaman, total simpanan, frekuensi membayar simpanan termasuk kategori sangat baik. Tingkat pengembalian pinjaman dianggap termasuk kategori kurang atau rendah. Hal ini berarti bahwa pengembalian pinjaman sangat mempengaruhi tingkat partisipasi anggota, semakin tinggi tingkat pengembalian pinjaman semakin tinggi partisipasi anggota dalam memanfaatkan layanan koperasi. Walaupun data kemacetan kredit hanya mencapai $0,3 \%$ per tahunnya, namun keadaan ini bertaut erat dengan ketegasan pengurus dan karyawan terhadap perilaku anggota dalam pembayaran pinjaman anggota, yaitu ketegasan pengembalian pinjaman melalui pemotongan gaji dan pendapatan lain yang diperoleh anggota.

Partisipasi insentif anggota koperasi termasuk kategori baik. Partisipasi insentif yang termasuk kategori baik meliputi frekuensi memberi saran untuk menentukan keputusan layanan simpan pinjam, penyampaian keluhan dan kritikan, pengawasan terhadap kegiatan USP. Selanjutnya indikator frekuensi kehadiran menghadiri rapat anggota usulan tata cara pembayaran, keaktifan dalam memenuhi simpanan-simpanan termasuk kategori cukup.

\section{Gambar 2. Citra Layanan USP dan Partisipasi Anggota Koperasi Fungsional $X$}

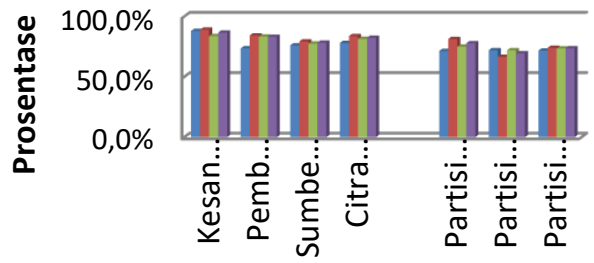

Gambar 2.

Citra Layanan USP dan Partisipasi Anggota Koperasi Fungsional $X$

Dari gambaran tersebut nampak bahwa terdapat hubungan yang kuat antara citra layaan USP koperasi dengan partisipasi angggota. Dengan demikian semakin baik citra layanan USP koperasi, maka akan semakin tinggi tingkat partisipasi anggota koperasi.

\section{KESIMPULAN DAN SARAN}

Kesimpulan. Pencitraan unit USP Koperasi Fungsional X Provinsi Lampung mampu membangun citra yang positif bagi anggota koperasi. Pencitraan termasuk 
kategori sangat baik. Terdapat beberapa indikator citra layanan yang yang masih termasuk kategori kurang yaitu penggunaan teknologi/komputerisasi layanan yang belum tersedia dan belum memadai serta pandangan pihak lain yang menganggap koperasi belum berprestasi melakukan pelayanan. Kedua indikator ini yang menimbulkan citra negatif terhadap koperasi.

Partisipasi kontributif maupun insentif anggota koperasi termasuk kategori baik. Jenis partisipasi yang relatif kurang adalah tingkat pengembalian pinjaman, karena gaji tidak mencukupi untuk menutupi cicilan pinjaman.

\section{Saran}

a. Salah satu upaya yang perlu dilakukan untuk meningkatkan pelayanan pinjaman adalah pengadaan formulir atau isian tentang pengajuan pinjaman, kontak saran unuk menampung keluhan dan kritik membangun bagi perbaikan layanan koperasi bagi anggota.

b. Pengurus dan karyawan koperasi harus lebih proaktif memberi informasi besaran, waktu, dan skim layanan simpan pinjam kepada anggota secara rutin menggunakan media cetak maupun elektronik dan media sosial anggota koperasi. Koperasi perlu menyediakan fasilitas layanan pinjaman di USP Koperasi dengan layanan teknologi yang terbuka dan terkendali yang mempercepat proses pencairan pinjaman maupun pembayaran pengembaliannya.

\section{DAFTAR PUSTAKA}

Alma, Buchari. 2010. Pengantar Bisnis. Penerbit PT Gramedia Pustaka. Jakarta

Effendi, Onong Uchyana. 1988. Ilmu Komunikasi Teori dan Praktek. Penerbit PT Remaja Rosda Karya. Bandung

Hanel, Alfred. 1989. Organisasi Koperasi. Pokok-pokok Pemikiran Mengnei Organisasi Koperasi dan Kebijakan Pengembangannya di Negra-negara Berkembang. Penerbit Unpad. Bandung.

Hendar dan Kusnadi. 1999. Ekonomi Koperasi. Penerbit Fakultas Ekonomi Universitas Indonesia. Jakarta.

Kotler, 1995. Manajemen Pemasaran, Jakarta Priyatna, Soeganda dan Elvinaro Ardianto. 2009. Tujuh Pikar Strategi Komunikasi Bisnis. Penerbit Widya Padjadjaran. Bandung

Ramudi Arifin. 1997. Ekonomi Koperasi. Penerbit Ikopin. Bandung

Ropke, Jochen. 2000. Ekonomi Koperasi, Teori dan Manajemen. Penerbit Salemba Empat, Fakultas Ekonomi Unpad. Bandung.

Rusidi. 2004. Metodologi Penelitian. Jilid 1 dan 2. Penerbit UPT Ikopin. Jatinangor. Bandung

Soewardi Herman. 1995. Filsafat Koperasi dan Cooperativism. Ikopin.Jatinangor.

Soemirat Soleh dan Elvinaro Ardianto. 2004. Dasar-dasar Public Relation. Penerbit PT Remaja Rosdakarya. Bandung. 
Vol. 2, No. 2, Desember 2017: 291-357 AGRICORE-Jurnal Agribisnis dan Sosial Ekonomi Pertanian 